\title{
Effects of Logging on Stand Damage in the Rainforest of South-eastern Nigeria
}

\author{
F. E. Bisong ${ }^{1 *}$ and P. Mfon ${ }^{2}$, Jnr \\ ${ }^{\prime}$ Department of Geography and Regional Planning, University of Calabar, P. O. Box 3733, \\ Calabar, Nigeria \\ ${ }^{2}$ Cross River State Forestry Commission, P. 0. Box 1296, Calabar, Nigeria \\ *Corresponding author; E-mail: febisong@yahoo.com
}

\begin{abstract}
Study was carried out in the tropical high forest of Iwuru community in south-eastern Nigeria to examine the extent of stand damage to unlogged trees at different logging intensities. Twenty four plots of 1 ha each were laid and were classified as lightly logged, moderately logged, severely logged and unlogged (control). Each category had six plots. Data on level of tree damage was taken and calibrated into various classes as "good", "minimal", "moderate", and "severe" damage. Means, analysis of variance and the post hoc test were the statistical models employed to analyze data. A positive correlation was observed between logging intensities and damage level to stands of non-logged trees with the number of trees destroyed increasing with logging intensity. Data on stocking indicated that the unlogged plot had a statistical mean of 41.5833 and a sum of $38.8 \%$, which was the highest. The lowest statistical mean of 12.2083 and the sum of $11.4 \%$ were for severely logged plots, indicating that the population of unlogged trees diminished with increasing logging intensity. Also, the large $\mathrm{F}$ value (11.971) and the low $\mathrm{P}$ value $(0.000)$ indicated that logging intensity had significant contribution to the extent of damage to unlogged trees in the various sample plots. The post hoc test gave a value of 0.839 , which is positively significant, indicating a significant, contribution of logging intensities to the damage done to unlogged trees.
\end{abstract}

\section{Introduction}

Despite the great values of the tropical rain forests in terms of its tremendous biodiversity component, which is vital to the existence of mankind, there are threats of mass elimination of species mainly as a result of unsustainable human activities which include logging. Cross River State in south-eastern Nigeria has over $40 \%$ of the remaining tropical high forest of the country and the rural communities in the state including Iwuru (study area) depend on the exploitation of the rich biodiversity of the tropical high forests in their environment (Bisong, 1994; Ajake, 2001).

The degree of change in the forest of Cross River State, arising from logging related activities, is enormous when seen in the light of recent forest cover change statistics. While total deforested area increased by $22.5 \%$ in Cross River State between 1991 and 2001, degraded and fragmented forests increased by an astronomic 522\% (Flasse, 2002). This brings to light the problems posed by logging to forest conditions, as it is the greatest singular factor responsible for forest degradation in the region.

The rapidity of forest losses, through logging operations and its possible source of concern, selective and clear-cut systems of logging and any amount of forest disturbance could result in the alteration of the forest environment with consequences on the biodiversity component and the forest structure (Janzen, 1970; Hamilton, 1988). This study seeks to assess the damage caused by logging operations to unlogged trees in the tropical high forests of the Iwuru community of south-eastern Nigeria.

There exist several empirical studies focused on the impact of logging on stand damage. Sist \& Bertault (1998) in the dipterocarp forests of East Kalimantan in South-east Asia have examined the impact of logging intensities and techniques on stand damage both in terms of commercial timber volume extracted and reduced impact logging (RIL) techniques by comparing the pre- and post harvesting stand inventories. Timber volume obtained averaged $87 \mathrm{~m}^{3} \mathrm{ha}^{-1}$ (i.e. 
$53.8 \%$ of the felled volume). Averagely, logging damage affected about $40 \%$ of residual tree stands $(\mathrm{dbh}>10 \mathrm{~cm})$. The injured and dead trees were estimated in equivalent proportion of $21 \%$ and $19 \%$, respectively.

Felling operations generally caused injuries to trees, crown damage being much; however, skidding resulted in deaths to trees by uprooting. Injuries and death to trees from RIL comparably was lower $(30.5 \%)$ than conventional methods $(48.1 \%)$. This study showed that the impact of logging on trees can be effectively reduced by strict supervision and planning of logging operations, and recommended that logging intensity should not be above $80 \mathrm{~m}^{2} \mathrm{ha}^{-1}$. By adhering to these technical recommendations its possible to reduce damage to unlogged tree stands by $20 \%$, which is equivalent to about $100 \mathrm{stems} \mathrm{ha}^{-1}(\mathrm{dbh}>10 \mathrm{~cm})$.

Crome et al. (1992) investigated logging damage in upland rain forests in North Queensland in Australia with respect to selective logging system, and observed that logged trees were mainly in long ridges and mean harvesting were 6.6 stems, $4.9 \mathrm{~m}^{2}$ basal area and $37 \mathrm{~m}^{2}$ logs ha- $\mathrm{s}^{-1}$. The highest level of losses from the whole stands was in the smallest and largest size classes, with an average of $146.7 \mathrm{stems} \mathrm{ha}^{-1}$ and $12 \mathrm{~m}^{2} \mathrm{ha}^{-1}$. About $22 \%$ of the tree canopies were lost while no tree species was eliminated. The study recommended the extraction of more timber from the crown of extracted trees, increasing winching and enhancing the expertise of field personnel towards reducing damage.

In the study of logging impact and prospects for sustainable forest management in the Amazonian frontier with focus on paragominas (Verissimo et al., 1990), it was discovered that an average of six trees were harvested per hectare in logging operations ( $\mathrm{n}=3$ study area) and the volume yield averaged $38 \mathrm{~m}^{2} \mathrm{ha}^{-1}$. Damage to the forest by logging was significant. It was recorded that 27 trees that were $10 \mathrm{~cm}$ dbh or more in girth were severally damaged for each tree extracted. The damages were recorded in the opening of approximately $40 \mathrm{~m}$ of logging road and $600 \mathrm{~m}^{2}$ of canopy per tree harvested.

Significant damage has been equally reported in the opening up of logging roads, felling and extraction of trees in tropical forests. The study reported by Verissimo et al. (1990) recorded that an average of six trees extracted ha ${ }^{-1}$ in the three study sites up to 150 trees ha-1 (greater than or equal to $10 \mathrm{~cm} \mathrm{dbh}$ ) were severely damaged. This translates into severe damage of about $27 \%$, $35 \%$ and $43 \%$ of all trees greater than or equal to $10 \mathrm{~cm}$ dbh present in the selected areas, respectively. About half (48\%) of the damaged trees were uprooted, $41 \%$ had broken stems and the rest $(11 \%)$ were observed to have suffered severe bark damage. Trees damaged in the areas studied ranged between $10-93 \mathrm{~cm}$ dbh and were averaged $20 \mathrm{~cm} \mathrm{dbh}$.

Jonkers (1988) in a similar study for the same area revealed that the harvesting of $18 \mathrm{~m}^{2}$ damaged $5 \mathrm{~m}^{2}$ of basal area in some sites. In others, where over three times this volume was harvested, basal area damage went up by more than $50 \%$. Thus, higher yields resulted in substantially less damage of every $\mathrm{m}^{-3}$ extracted. About $32 \%$ of damaged stands were economic species of high importance, $44 \%$ were highly valuable for rural construction but not presently sawn, while the remaining $24 \%$ of the damaged trees have no present or potential value for wood related uses.

There is a clear absence of empirical studies delineating logging effects on stand damage in south-eastern Nigeria. The study seeks to fill this gap in the literature by examining the effects of logging at different levels of intensity on damage to non-logged tree stands as well as proffer

solutions that minimizes the negative consequences of logging on forest stands and diversity. The hypothesis put forward to this effect is that logging at different levels of intensity cause no significant damage to the stands of unlogged trees.

\section{Materials and methods}


The study area, Iwuru community, is located within the confines of the tropical rain forests in latitude $05^{\circ} 24^{\prime} 03$ " $\mathrm{N}$ and longitude $08^{\circ} 13^{\prime} 19^{\prime \prime} \mathrm{E}$ in Akamkpa Local Government Area (LGA) of Cross River State (CRS) in south-eastern Nigeria. It is approximately $65 \mathrm{~km}$ north of Calabar (latitude $4^{\circ} 50^{\prime} 00^{\prime \prime} \mathrm{N}$ and longitude $8^{\circ} 15^{\prime} 00^{\prime}$ ' E), the state capital of Cross River State.

The land area of Iwuru in Akamkpa LGA is generally characterized by undulating surface. The rocks include the Precambrian crystalline basement rocks, while the different types of associated rocks found in the area include Gneissic and Migmattic rocks. (Rahman et al., 1981). The soil is both podzolic and lateritic naturally. Therefore, it has a high level of iron oxides, kaolin clay and aluminium compounds. This is as a result of very heavy leaching due to high annual rainfall (Asuquo, 1987).

The climate of Iwuru and indeed the whole of Akamkpa LGA is tropical humid in nature. The rainfall is between 250 and $500 \mathrm{~mm}$ from April to November. Between May and October, precipitation rises above $2000 \mathrm{~mm}$. The temperature ranges from 25 to $27{ }^{\circ} \mathrm{C}$ by January but in July, it hovers slightly above $30{ }^{\circ} \mathrm{C}$. Relative humidity is about $75-95 \%$ in January but, towards the end of the year, it reduces gradually as a result of the harmattan (Asuquo, 1987). This unique combination of high rainfall, humidity and temperature have interplayed to develop an equally unique, highly complex and most diversity rich vegetation, which is evergreen throughout the year.

The vegetation is evergreen tropical rain forest, which is a form of closed forest of which both the tropical and moist deciduous and semi-deciduous forests found outside West Africa belong. The tropical rain forest is a unique community of plants and animals (Park, 1992). This ecological zone in Iwuru is highly rich in biodiversity like all other tropical rain forests. The tree height ranges from $50 \mathrm{~m}$ to about $65 \mathrm{~m}$ and sometimes above the later height.

There are three distinct layers of trees which have emerged. These include the upper, middle and lower layers. The canopies at the upper layer are usually very closely arranged with reduced sunlight getting to the middle layer canopies and even a more reduced level of sunlight reaching the lower layer. Therefore, the lower layer has much more undergrowth in which herbs and shrubs are usually found, and several species of animals dwell in these forests. They include endemic ones such as the Guenon monkey, some wide varieties of reptiles, mammals, insects, birds and microbes. Some of these animals alternate for feeding, living and procreation at different niche levels in the forests. The forest is the home of highly valuable tropical hard woods and non-timber forest products on which the rural and regional economies depend.

The study of field measurement adopted the stock inventory method (SIM). Field observations and measure-ments were carried out on 24 sample plots classified into sites with different logging intensities. This ranged from unlogged plot as control to lightly, moderately and severely logged plots. Measurements obtained on each of these plots were the number of forest trees felled, and the number and levels of trees damaged.

\section{Sampling technique}

The stratified random sampling technique was employed for the collection of data in order to ensure that relevant areas with different logging activities were sampled. Of the total of 24 sample plots laid, six plots on the whole were allocated to each stratum (i.e. the unlogged, lightly logged, moderately logged and severely logged plots). Each plot was 1 ha in size $(100 \mathrm{~m} \times 100$ $\mathrm{m})$. Trees from $30 \mathrm{~cm}$ dbh and above were considered because in the forestry practice of Cross River State, a plant is considered as a tree when it has reached a minimum girth of $30 \mathrm{~cm}$.

\section{Classification and plot assessment criteria}

The level of canopy cover and the number of trees (30 $\mathrm{cm}$ and above) per hectare influenced this classification. For instance, a plot was classified as unlogged when it had between $90-100 \%$ canopy cover and the availability of between 106 and 160 'good' trees with dbh of $30 \mathrm{~cm}$ and 
above. Lightly logged plots had about 70-89\% canopy cover with 50-105 trees with dbh of 30 $\mathrm{cm}$ and above. For moderately logged plots, the canopy cover ranged from 50 to $69 \%$ with 'good' trees ranging from 10-49 with the prescribed dbh per hectare. Severely logged plot had less than 50\% canopy cover with trees ranging from 29-35 trees of the said dbh per hectare.

Canopy cover was assessed subjectively. The researchers stood within each plot and through ocular estimation divided the canopy areas into 10 parts and if one part was completely open, that represented $10 \%$ opening and if two parts were open, then $20 \%$ canopy opening was recorded.

\section{Classification of the level of stand damage}

Indicators for quality of tree stands sampled were "good", "minimal", "moderate" and "severe". A tree was regarded as "good" when there was no visible sign of injury on it. The term "minimal" was used when there was a slight injury on the tree, e.g. slight debarking while "moderate" was applied when at least a branch of the tree was broken and "severe" when the tree was uprooted or killed.

Data was analyzed through the use of statistical means and analysis of variance (ANOVA) to determine the extent of damage of tree stands at different logging intensities.

\section{Results and discussions}

The profile of tree stand damage under different logging intensities for the 24 sample plots is shown in Table 1. There were more "good" trees in unlogged plots while severely logged plots had the least number of such trees. This goes to confirm that logging intensity is directly proportional to the number of good trees found in a plot, i.e. as the intensity increases, the number of good trees decreases. Similarly, unlogged plots had the least number of severely damaged trees while the highest number was found in severely logged plots. The finding shows that the number of severely damaged trees increases with the intensity of logging.

\section{TABLE 1}

Damage to unlogged trees in sample plots with different logging intensities

No Description of sample plots

1. Unlogged plot

2. Severely logged plot

3. Moderately logged plot

4. Lightly logged plot

5. Moderately logged plot

6. Lightly logged plot

7. Unlogged plot

8. Severely logged plot

9. Moderately logged plot

10. Lightly logged plot

11. Unlogged plot

12. Unlogged plot

13. Severely logged plot

14. Severely logged plot

15. Lightly logged plot

16. Unlogged plot

17. Lightly logged plot

18. Moderately logged plot

19. Severely logged plot
Damaged level to unlogged trees on sample plots (trees less than or equal to $30 \mathrm{~cm} \mathrm{dbh}$ )

Good Minimal Moderate Severe Total

$\begin{array}{rrrrr}142 & 17 & 9 & 2 & 170 \\ 4 & 16 & 14 & 21 & 51 \\ 10 & 23 & 30 & 22 & 85 \\ 80 & 25 & 21 & 10 & 136 \\ 15 & 20 & 40 & 11 & 86 \\ 74 & 16 & 15 & 15 & 120 \\ 135 & 20 & 10 & 6 & 171 \\ 10 & 3 & 7 & 20 & 40 \\ 11 & 15 & 32 & 18 & 76 \\ 75 & 30 & 27 & 20 & 152 \\ 106 & 30 & 12 & 2 & 150 \\ 160 & 17 & 10 & 3 & 190 \\ 5 & 9 & 16 & 5 & 55 \\ 6 & 7 & 8 & 17 & 36 \\ 76 & 22 & 17 & 13 & 128 \\ 130 & 15 & 10 & 5 & 160 \\ 90 & 21 & 11 & 10 & 132 \\ 20 & 23 & 26 & 14 & 81 \\ 6 & 21 & 10 & 23 & 60\end{array}$




\begin{tabular}{|c|c|c|c|c|c|}
\hline 20. Severely logged plot & 2 & 7 & 15 & 21 & 45 \\
\hline 21. Lightly logged plot & 69 & 24 & 18 & 15 & 126 \\
\hline 22. Unlogged plot & 128 & 14 & 11 & 4 & 157 \\
\hline 23. Moderately logged plot & 18 & 28 & 29 & 4 & 79 \\
\hline 24 Moderately logged plot & 21 & 32 & 19 & 11 & 83 \\
\hline
\end{tabular}

Source: Researcher's field work (2002)

To summarise patterns of tree damage, the statistical means of data in Table 1 was derived and shown in Table 2. The results reveal that the greater number of undamaged trees (Table 2, row A) is to be found in the unlogged sample sites with the mean value of trees not damaged put at $122.67 \mathrm{ha}^{-1}$. Corres-pondingly, only very few trees with no damage with mean value of $5.5 \mathrm{ha}^{-1}$ are to be found in the severely logged sites. As logging intensity progresses, a sharp reversal can be noticed with regards to the damage level of tree stands (Table 2, row E) with unlogged plots recording the lowest mean of severely damaged stands $\left(4.6 \mathrm{ha}^{-1}\right)$, while the highest mean of severely damaged tree stands $\left(21.6 \mathrm{ha}^{-1}\right)$ are to be found in the severely logged plots. The result of this simple analysis indicates that the severity of damage to tree stands in tropical rain forest environments occurs with increasing logging intensity.

TABLE 2

(A-E) Statistical means of difference in the stand damage of unlogged trees found in sample plots

\begin{tabular}{|c|c|}
\hline $\begin{array}{c}\text { Extent of damage to } \\
\text { unlogged trees }\end{array}$ & Sample plots \\
\hline
\end{tabular}

$\begin{array}{llrr}\text { A. No damage } & \text { Unlogged } & 122.6667 & 34.0920 \\ & \text { Lightly logged } & 75.0000 & 10.3150 \\ & \text { Moderately logged } & 15.8333 & 4.6224 \\ & \text { Severely logged } & 5.5000 & 2.6646 \\ & \text { Total } & 54.7500 & 51.1870 \\ \text { B. Minimal damage } & \text { Unlogged } & 24.1667 & 11.9569 \\ & \text { Lightly logged } & 23.6667 & 5.0859 \\ & \text { Moderately logged } & 23.5000 & 5.9582 \\ & \text { Severely logged } & 10.6667 & 6.5929 \\ & \text { Total } & 20.5000 & 9.3576 \\ \text { C. Moderately damage } & \text { Unlogged } & 14.8333 & 11.3915 \\ & \text { Moderately logged } & 29.3333 & 6.9186 \\ & \text { Severely logged } & 11.5000 & 4.0373 \\ & \text { Total } & 18.5417 & 9.7801 \\ \text { D. Severe damage } & \text { Unlogged } & 4.6667 & 3.0768 \\ & \text { Lightly logged } & 14.5000 & 4.3243 \\ & \text { Moderately logged } & 13.3333 & 6.25 .3 \\ & \text { Severely logged } & 21.1667 & 2.7142 \\ & \text { Total } & 13.4167 & 7.2226 \\ & \text { Unlogged } & 14.5833 & 51.4823 \\ \text { E. Total } & \text { Lightly logged } & 32.9167 & 25.8153 \\ & \text { Moderately logged } & 20.5000 & 8.5465 \\ & \text { Severely logged } & 12.2083 & 3.0401 \\ & \text { Total } & 26.8021 & \\ & & & \end{array}$

Fig. 1 graphically presents the data (Table 1) on damage to unlogged tree species in sample plots with different logging intensity. It is noticed that the highest population of species quantitatively grouped as "good" is found in the unlogged plots (736 individuals) while the least 
is found in intensively logged sampled plots (33 individuals). Lightly logged sample plots have the next highest population of "good" species and moderately logged plots follow this. From these, the "good" individuals reduce as logging intensity increases.

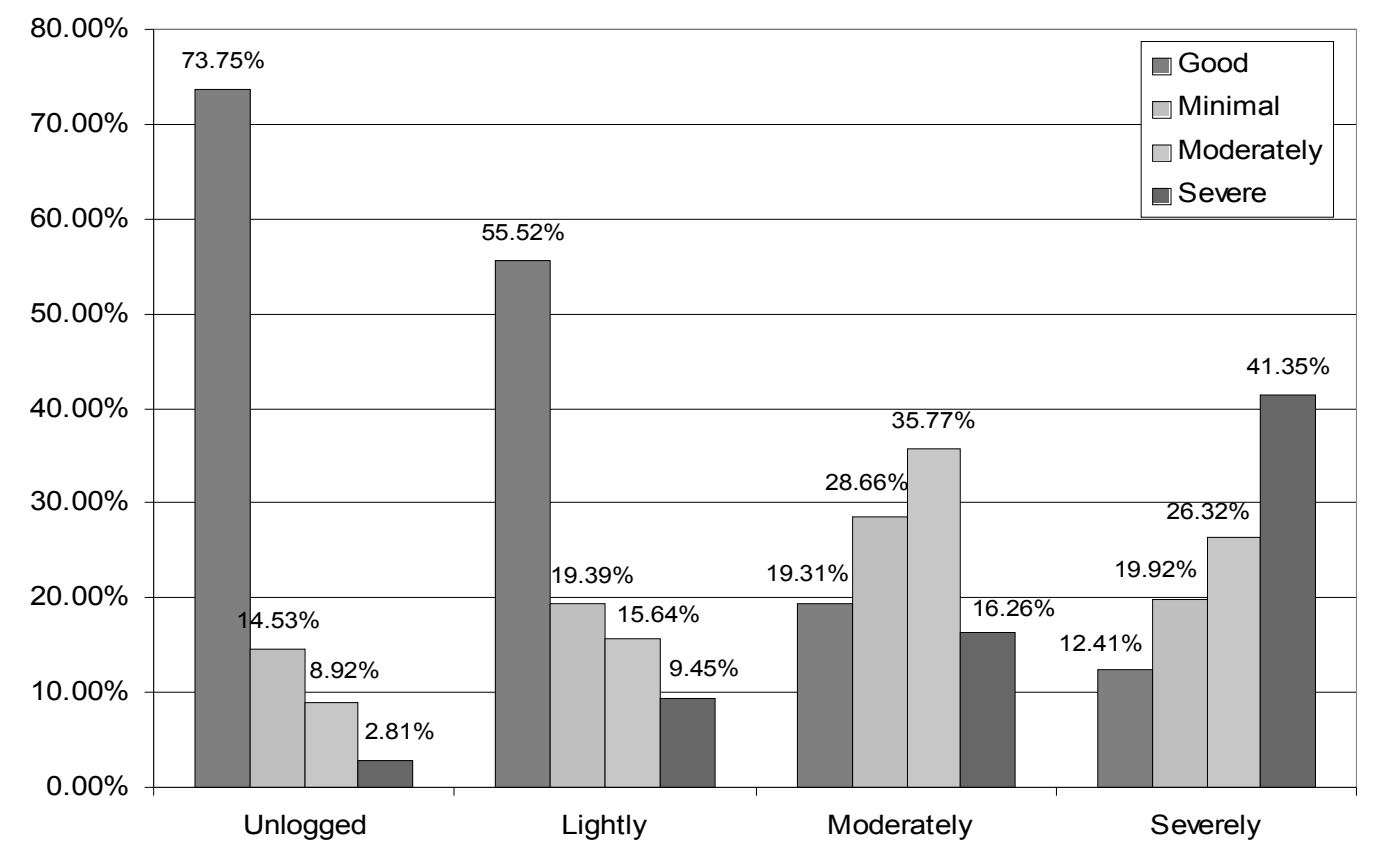

Fig. 1. Graphical presentation of damage to unlogged trees in sample plots with different logging intensities

Species graded as having minimum damage in unlogged sample plots are 145 individuals, which is almost the same with the values of 142 and 141 individuals, respectively, in lightly logged and moderately logged sample plots. Since the lowest value is observed in intensively logged sample plots (64 individuals), then it can be interpreted that the quantity of species graded as having minimal damage also reduces (this time, gradually) as logging intensity increases. Fig. 1 also reveals that the population of individual plant species graded as "moderately damaged" is 89 in unlogged plots and rises to 111 individuals in lightly logged plots, the highest observation of 176 individuals in moderately logged plots, and the lowest observation of 127 individuals in the intensively logged plots.

The population graded as having "severe damage" shows an increasing and progressive trend from the lowest value of 28 individuals in unlogged plots to 127 individuals in intensively logged plots. Although the values in the lightly and moderately logged plots are similar, this shows that the higher the intensity of logging, the higher the population of the quantity of plants severely damaged. The values indicating the "totals" actually describe the quantity enumerated in each sample plot types, with the highest population of encountered species observed in the unlogged plots (998), while the lowest population (293) is recorded in the intensively logged plots (a difference of 705 individuals). This indicates that logging significantly reduces the quantity of tree species in the logged tropical rainforests of Iwuru.

Subjecting the data in Table 1 to a more rigorous statistical analysis through the application of a difference of mean test (ANOVA) as shown in Table 3, it may be inferred from Table 3 that a significant statistical difference exists in the severity of tree damage on the basis of differential logging intensities. From the Table, the F-value is relatively large (11.971), while the p-value is 0.000. Where F-value is large and significance level small (i.e. less than 0.05 or 0.01 ), the 
hypothesis of no difference may be rejected, and concluded that no significant difference exists in the damage level of trees on the basis of differential logging intensities at less than 0.01 probability.

TABLE 3

Analysis of variance on damage level of unlogged trees in sample plots

\begin{tabular}{|c|c|c|c|c|c|c|c|c|}
\hline & & & Numb & $\begin{array}{r}\text { Descr } \\
\text { er of unlog }\end{array}$ & $\begin{array}{l}\text { ptive } \\
\text { yed trees } i\end{array}$ & ots & & \\
\hline & $N$ & Mean & $\begin{array}{l}\text { Standard } \\
\text { deviation }\end{array}$ & $\begin{array}{l}\text { Standard } \\
\text { error }\end{array}$ & $\begin{array}{r}95 \% \mathrm{cc} \\
\text { interval }\end{array}$ & $\begin{array}{l}\text { dence } \\
\text { mean }\end{array}$ & Minimum & Maximum \\
\hline & & & & & Lower & Upper & & \\
\hline & & & & & bound & bond & & \\
\hline No damage & 24 & 54.7500 & 51.1870 & 10.4485 & 33.1356 & 76.3644 & 2.00 & 16.00 \\
\hline Minimal damage & 24 & 20.5000 & 9.3576 & 1.9101 & 16.5486 & 24.4514 & 3.00 & 46.00 \\
\hline Moderate damage & 24 & 18.5417 & 9.7801 & 1.9964 & 14.4119 & 22.6714 & 7.00 & 40.00 \\
\hline Severely damage & 24 & 13.4167 & 7.2226 & 1.4743 & 10.3668 & 16.4665 & 2.00 & 25.00 \\
\hline Total & 96 & 26.8021 & 31.0031 & 3.1642 & 20.5203 & 33.0839 & 2.00 & 16.00 \\
\hline
\end{tabular}

$\begin{array}{lrrcccc} & \text { Sum of square } & D & f & \text { Mean square } & F & \text { Significance } \\ & & & & & \\ \text { Between group } & 25636.948 & 3 & 8545649 & 11.971 & 0.00 \\ \text { Within groups } & 65676.292 & 92 & 713.873 & & \\ \text { Total } & 91313.240 & 95 & & & \end{array}$

The post hoc test carried out on the same data set in Table 1 is presented in Table 4 and further suggests the need to reject the null hypothesis as suggested by the two previous analyses (i.e. statistical means and analysis of variance). The degree of relationship of the variables as shown by the post hoc test is given as 0.839 . This indicates a very significant contribution of logging intensities to damage done to unlogged trees. Consequently, the null hypothesis, which states that "logging intensity has made no significant contribution to the extent of damage to unlogged trees in the logged forests in Iwuru" is rejected, and the alterna-tive hypothesis that "logging intensity has made significant contributions to the level of damage to unlogged trees in the logged forests of Iwuru" is accepted.

TABLE 4

Post hoc test (multiple comparisons) of data on damage to unlogged trees in sample plots

\begin{tabular}{|c|c|c|c|c|c|c|}
\hline \multirow{2}{*}{$\begin{array}{l}\text { Extent of damage } \\
\text { to unlogged trees } \\
\text { (i) }\end{array}$} & \multirow{2}{*}{$\begin{array}{c}\text { Extent of damage } \\
\text { to unlogged } \\
\text { trees }(j)\end{array}$} & \multirow{2}{*}{$\begin{array}{c}\text { Mean } \\
\text { difference } \\
(i-j)\end{array}$} & \multirow{2}{*}{$\begin{array}{c}\text { Standard } \\
\text { error }\end{array}$} & \multirow[t]{2}{*}{ Significance } & \multicolumn{2}{|c|}{$95 \%$ confidence interval } \\
\hline & & & & & $\begin{array}{c}\text { Lower } \\
\text { bond }\end{array}$ & $\begin{array}{c}\text { Upper } \\
\text { bond }\end{array}$ \\
\hline \multirow[t]{3}{*}{ No damage } & Minimal damage & $34.2500 *$ & 7.7129 & 0.000 & 12.2840 & 56.2160 \\
\hline & Moderate damage & $36.2083^{*}$ & 7.7129 & 0.000 & 14.2423 & 58.1743 \\
\hline & Severe damage & $41.3333^{*}$ & 7.7129 & 0.000 & 19.3673 & 63.2993 \\
\hline \multirow[t]{3}{*}{ Minimal damage } & No damage & $-34.2500^{*}$ & 7.7129 & 0.000 & -56.2160 & -12.2840 \\
\hline & Moderate damage & $1.9583 *$ & 7.7129 & 0.996 & -20.0077 & 23.9243 \\
\hline & Severe damage & $7.0833^{*}$ & 7.7129 & 0.839 & -14.8827 & 29.0493 \\
\hline \multirow[t]{3}{*}{ Moderate damage } & No damage & $-36.2083^{*}$ & 7.7129 & 0.000 & -58.1743 & -14.2423 \\
\hline & Minimal damage & $-1.9583^{*}$ & 7.7129 & 0.996 & -23.9243 & 20.0077 \\
\hline & Severe damage & $5.1250^{*}$ & 7.7129 & 0.931 & -16.8410 & -27.0910 \\
\hline
\end{tabular}




\begin{tabular}{|c|c|c|c|c|c|c|}
\hline \multirow[t]{3}{*}{ Severe damage } & No damage & $-41.3333^{*}$ & 7.7129 & 0.000 & -63.2993 & -19.3673 \\
\hline & Severe damage & $-7.0833^{*}$ & 7.7129 & 0.839 & -29.0493 & 14.882 \\
\hline & $M$ & * & 0 & $0 \mathrm{C}-3$ & -270910 & 16.8410 \\
\hline
\end{tabular}

* The mean difference is significant at the 0.05 level.

\section{Recommendations}

The findings from the research have revealed that logging intensity significantly influences forest stand damage and that the higher the logging intensity, the greater the damage to the forest flora population. Consequently, these could have dire effect on the general forest ecosystem and severe implications on the availability of socio-economic, industrial and medical (health) products by population dependent on natural resources obtainable from the tropical rain forests. To ameliorate or totally eradicate these possible problems, the following recommendations have been made.

The concessional programme for allocation of tropical rain forests for logging should include the monitoring and actual co-ordination of the logging activities. Stock surveys should be carried out while the trees to be logged should be carefully selected and marked out by officials of the Forestry Commission. Severe penalties should be meted out to law-breakers. Forest areas with rare endemic species should not be logged while sloppy areas, which are highly prone to erosion, should be excluded from logging.

There should be a compulsory system of replacement of at least three seedlings for every one tree logged. Emphasis should be given to indigenous species over exotic ones. No logging should be carried out close to streams and other perennial water sources. Participatory management strategies incorporating the multiple views and opinions of the various tiers of government, com-munities, local and international non-government agencies (NGOs) should be encouraged.

The possible consequence of logging activities on NTFPs and wildlife populations on which rural populations depend largely should be a priority in the list of factors considered for granting logging concessions. Most productive NTFPs collection areas should be protected from logging operators. More environmental friendly logging strategies should be identified through increased research and encouraged. Minimum and maximum logging intensities for all logging concession areas should be stipulated, and highly destructive machines and vehicles discouraged from the area.

The construction of logging roads and log retrieval trails should be planned before logging operations commence. This should be based on mapping strategies which reduce the opening of the forest to other users (such as farmers, hunters and house developers), and at the same time reduce forest destruction.

The importance of forest disturbance and canopy openings to regeneration of certain commercially favoured timber species and NTFPs should be identified and such moderate processes should not be totally discouraged. There should be pre-logging environmental impact assessments which culminate in the submission of environmental impact assessment reports on which logging operations can be executed.

An increasingly high proportion of the income from felled trees and NTFPs should go to the rural communities or individuals as the case may be. This would encourage natural resource conservation since the rural people so deprived of possibly using the forest areas for farming can still earn valuable income.

Logging companies and even powered chain-saw logging operators should be mandated to be involved in rural Infrastruc-tural development, employment of the members of the host communities, and support of other socio-economic activities of such host rural settlements. 
Adequate funds should be provided by government, individuals and non-govern-mental organizations (NGOs) with the view to raising nurseries and plantations. Also, more forestry personnel should be employed, trained and motivated in order to police the forest and reduce the indiscriminate felling of trees.

\section{References}

Ajake A. O. (2000). Women in Forest Resources Use and Management in the Akamkpa Local Government Area of Cross River State. (MSc.Thesis.). Department of Geography and Regional Planning, University of Calabar, Calabar, Nigeria.

Asuquo F. A. (1987). Soils and Vegetation of South Eastern Nigeria. Prestige Press Limited, Lagos.

Bisong F. E. (1994). Farming Systems, Human Ecology and Natural Resource Conservation. A Report to the Cross River State Forestry Department, Calabar, Nigeria.

Chrome F. H. J, Moore L. A. and Richards G. C. (1992). A Study of Logging Damage in Upland Rainforest in North Queensland, Aust. For. Ecol. Mgmt 49: 1-29.

Flasse (2002). A Participatory Appraisal of the Forest of Cross River State. The Cross River State Community Forestry Project. Forestry Commission, Calabar, Nigeria.

Hamilton L. S. (1988). Minimizing the Adverse Impacts of Harvesting in Humid Tropical Forests. Winrock International Institute for Agricultural Development, Morrilton.

Janzen D. H. (1970). Herbivores and the Number of Tree Species in Tropical Forests. Am. Nat. 104: 501-528.

Jonkers W. B. J. (1988). Vegetation Structure Logging Damage and Silviculture in Tropical Rainforests in Suriname. The Netherlands Agricultural University, Wageningen.

Rahman A. A. M. S, Ukpong E. E. and Azimatullah M. (1981). Geology and part of the Oban Massif South Eastern Nigeria. J. Min. Geol. 18(1): 60-65.

Sist P. and Bertault J. G. (1998). Reduced Impact Logging Experiments: Impact of Harvesting intensities and Logging Techniques on Stand Damage. In Silvicultural Research in Lowland Mixed Dipterocarp Forest of East Kalimantan. The contributions of STREK Project (J. G. Bertault and K. C. Kadir, ed.), pp. 139-161. CIRAD-JORET, Montpellier.

Verissimo A., Barreto P., Maltes M., Tarifa R. and Uhl C. (1992). Logging Impacts and Prospect for sustainable Forest Management in an old Amazon Frontier: The case of Paragominas. For.Ecol. Mgmt 55: 1-4. 